\title{
Short communication: Dipping efficiency and teat dip residues in milk using an automatic dipping system
}

\author{
W. Berg, ${ }^{* 1}$ S. Rose-Meierhöfer, ${ }^{*}$ C. Ammon, ${ }^{*}$ and C. Kobbe† \\ *Leibniz-Institute for Agricultural Engineering Potsdam-Bornim (ATB), Max-Eyth-Allee 100, 14469 Potsdam, Germany \\ †South Westphalia University of Applied Sciences, Department of Agriculture, Lübecker Ring 2, 59494 Soest, Germany
}

\begin{abstract}
Prototypes of the automatic-dipping system Apollo were tested with the IQ milking cluster (GEA Farm Technologies GmbH, Bönen, Germany) to determine the teat-dip residues in the milk and the dipping performance (number of dipped teats) of the system compared with manual (hand) dipping. A laboratory trial and a field trial at a dairy farm were performed to determine the iodine level in the milk when an iodine-based teat dip was used. In the laboratory trial, the mean difference between the 53 paired samples (sampling upstream and downstream of the cluster) was $18.9 \pm 3.18 \mu \mathrm{g}$ of iodine $/ \mathrm{kg}$. A field trial at a $300-$ cow commercial dairy farm consisted of taking 2 sets of individual cow milk samples $6 \mathrm{wk}$ apart. Three weeks before the second test day, the iodine-based teat dip was replaced by an iodine-free teat dip. The mean difference between the 2 sets of 55 samples was $25.1 \pm 5.22 \mu \mathrm{g} / \mathrm{kg}$. Compared with manually applying an iodine-based teat dip, the increase in the iodine content resulting from the use of the tested cluster with automatic dipping was very low and would not be an issue of food safety. The dipping performance tests were completed on the same 300-cow commercial dairy farm as the field iodine level trial was performed. In total, 4,541 teats from 307 cows were observed on 4 consecutive days, showing a $91.6 \pm 1.3 \%$ success rate.
\end{abstract}

Key words: dairy cow, milking, teat dipping, iodine

\section{Short Communication}

One of the most effective mastitis prevention techniques is applying an appropriately formulated disinfection solution to the cow's teat directly after machine milking. The teat is moist with nutrient-rich milk and the teat canal remains open right after milking, exposing the quarter to infection. The moist and vulnerable teats are subsequently exposed to bacteria-laden in-

Received June 27, 2013.

Accepted February 26, 2014.

${ }^{1}$ Corresponding author: wberg@atb-potsdam.de sects, bedding, manure, and so on throughout the day. Teat disinfection solution consistently applied directly after milking will kill contagious organisms on the skin surface along with covering the open teat canal with a germ-killing barrier (Boddie et al., 2004). In addition to the germ-killing components, the teat disinfection solution is formulated with skin-conditioning agents to reduce chapping and to help keep the teat skin smooth and supple. By reducing the cracks and crevices in the teat skin, fewer places exist for contagious organisms to colonize.

To reduce the need for labor and provide consistency, mundane and repetitive tasks, such as applying teat dip, are being automated. Several advantages exist of applying the teat dip at the end of the milking process directly through the liner dome. The teat is treated while it is under vacuum, stretched out, and flaccid, allowing the dip to penetrate deeply (Galton, 2004). The teat is also protected before the liner is removed, exposing the teat to the environment. Teat dip is applied in a controlled manner, reducing waste and reducing the worker exposure to automatized teat dip. Automated in-cluster teat dip applications have shown to be effective in reducing new IMI and improving herd health (Galton, 2004; Olde Riekerink et al., 2012). However, because the dip solution is being applied through the cluster, adequate protections need to be used to ensure milk safety. Therefore, GEA Farm Technologies GmbH (Bönen, Germany) has recently developed an in-liner dipping system (The Apollo MilkSystem) and the objective of this study was to assess the dipping performance and the system's ability to ensure milk safety.

In trial 1, a laboratory test was done to ascertain dipping residues in the milk. Just before the cluster was removed at the end of milking, the automated dipping system closed the long milk tube and automatically applied teat dip to the inside of the teat-liner head with an iodine-containing dipping solution. After the rinsing cycle was complete, a chance existed that some residual teat dip could be flushed out in a subsequent milking session. All trials were performed with a $0.5 \%$ iodine-based dip. The iodine content of the milk was 
analyzed in a certified laboratory using gas chromatography, which has an accuracy of $8.51 \mu \mathrm{g} / \mathrm{kg}$ and a repeatability of $24 \mu \mathrm{g} / \mathrm{kg}$.

Tests for teat-dip residues after cleaning and disinfection of the cluster were conducted at the LeibnizInstitute for Agricultural Engineering Potsdam-Bornim (ATB, Potsdam, Germany) testing environment. The testing environment was equipped with the same version Apollo IQ dipping cluster as the milking parlor tested in trials 2 and 3. Fresh chilled raw milk from the bulk milk tank of a neighboring dairy farm was heated to $25^{\circ} \mathrm{C}$. Using a milking vacuum system, the heated milk was passed via 4 flow controllers (total flow: $2.5-3 \mathrm{~L} / \mathrm{min}$ ) to 4 artificial teats (method ISO/ DIN 6690; ISO/DIN, 2007), to which the IQ cluster with automatic dipping was attached. Samples were taken from the milk flow upstream and downstream of the cluster. Sampling was done using a sampler (TruTest Ltd., Manukau, New Zealand). Ten milliliters of dipping solution was used for each dipping. During the subsequent automatic rinsing and disinfection of the cluster, the artificial teats were cleaned by hand with paper towels and the samplers were prepared for the next run.

A total of 53 sample pairs were taken in this way. The frozen milk samples were then sent to the abovementioned laboratory to determine the iodine content. The differences in the iodine content found upstream and downstream of the cluster were checked for a positive distinction from zero (1-sided paired $t$-test), using the TTEST procedure in SAS (version 9.2; SAS Institute Inc., Cary, NC).

Trial 2 was designed to determine the iodine level of the automated dipping system using an iodine-based teat dip (the same $0.5 \%$ iodine-based dip as also used in the other trials) and comparing it with the same system using a non-iodine-based teat dip on a dairy farm. Two sample sets were taken, one using iodine-based teat dip and the second set, 6 wk later, using a non-iodine-based teat dip. The iodine-based dipping solution was used with an amount of $12 \mathrm{~mL}$ per dipping. About 3 wk before taking the second set of samples, the iodine-based teat dip was replaced by a non-iodine-based teat dip. Of the 36 stalls in the rotary parlor, 18 were selected at random and equipped with samplers (Tru-Test Ltd.). Fifteen of these 18 stalls were the same for both sample sets. On the second test day, milk samplers could not be mounted at 3 stalls because of mechanical problems and were placed at 3 different stalls. Milk samples were taken on both test days after the start of milking until 55 samples with a sufficient quantity of milk had been collected for the laboratory analysis (corresponding to $\geq 13 \mathrm{~kg}$ of milk per milking). These 110 samples came from 93 cows randomly milked in the selected stalls. A mixed linear model was selected to ascertain the difference in the iodine content of the milk for the 2 dipping solutions:

$$
\mathrm{y}_{\mathrm{ijk}}=\mu+\mathrm{DS}_{\mathrm{i}}+\mathrm{S}_{\mathrm{j}}+\mathrm{C}_{\mathrm{k}}+\varepsilon_{\mathrm{ijk}}
$$

where $\mathrm{y}_{\mathrm{ijk}}=$ monitored milk iodine content, $\mu=$ general mean milk iodine content, $\mathrm{DS}_{\mathrm{i}}=$ fixed effect of the ith $\operatorname{dip}(i=1$ or 2$), S_{j}=$ fixed effect of the jth stall $(j=1$, . $\ldots, 21), \mathrm{C}_{\mathrm{k}}=$ random effect of the kth cow $(\mathrm{k}=1, \ldots$, $93)$, and $\varepsilon_{\mathrm{ijk}}=$ independent residual with normal distribution. The model was implemented with the MIXED procedure in SAS (version 9.2; SAS Institute Inc.).

Four milking sessions were observed at the same milking parlor as in trial 2 to determine if the teats were automatically dipped after removal of the cluster unit with automatic dipping function. A teat was considered dipped only if a drop of dip had formed at the end of the milk duct. Each udder was treated with $12 \mathrm{~mL}$ of dip. The lower $95 \%$ confidence limit for mean dipping success was estimated for a half-width of 2 standard deviations. For the necessary single-sided $t$-test, a minimum of 4 milking sessions had to be evaluated at a level of significance of $\alpha=0.05$ and an intended power of $90 \%$.

Quarters were classified as follows: quarter with drop formation (QDr), quarter without drop formation (QwoDr), and quarter without dipping (QwoD). The total of these quarters yielded the maximum number of quarters that needed to be dipped (Qmax). Accordingly, the dipping success (DS) was calculated as follows:

$$
\mathrm{DS}=[1-(\mathrm{QwoDr}+\mathrm{QwoD}) / \mathrm{Qmax}] \times 100 .
$$

The laboratory test was conducted to determine the dipping residues after cleaning and disinfection of the cluster (Table 1). The iodine content of the samples taken downstream of the cluster was, therefore, signifi-

Table 1. Iodine content in milk up- and downstream of the cluster

\begin{tabular}{lcccc}
\hline Sample & $\mathrm{n}$ & $\begin{array}{c}\text { Mean iodine } \\
\text { content }(\mu \mathrm{g} / \mathrm{kg})\end{array}$ & $\begin{array}{c}\mathrm{SD} \\
(\mu \mathrm{g} / \mathrm{kg})\end{array}$ & $\begin{array}{c}\mathrm{SE} \\
(\mu \mathrm{g} / \mathrm{kg})\end{array}$ \\
\hline Upstream & 53 & 61.94 & 16.56 & \\
Downstream & 53 & 80.89 & 22.35 & 3.18 \\
Difference $(P<0.0001)$ & & 18.94 & & 3 \\
\hline
\end{tabular}


Table 2. Iodine content in milk during the field test with iodine and with non-iodine dip

\begin{tabular}{lcccc}
\hline Sample & $\mathrm{n}$ & $\begin{array}{c}\text { Mean iodine } \\
\text { content }(\mu \mathrm{g} / \mathrm{kg})\end{array}$ & $\begin{array}{c}\mathrm{SD} \\
(\mu \mathrm{g} / \mathrm{kg})\end{array}$ & $\begin{array}{c}\mathrm{SE} \\
(\mu \mathrm{g} / \mathrm{kg})\end{array}$ \\
\hline Iodine dip & 55 & 69.74 & 27.68 & \\
Non-iodine dip 6 wk later & 55 & 45.86 & 19.80 & \\
Corrected difference $(P=0.041)$ & & 25.12 & & 5.22 \\
\hline
\end{tabular}

cantly higher than that of the samples upstream of the cluster $(P<0.0001)$. Corresponding iodine levels are shown in Figure 1.

The field tests in trial 2 were conducted to determine the dipping residues after cleaning and disinfection of the cluster under real conditions on the farm. The samples taken on the first testing day with an iodinebased dipping solution and the mean iodine content of the samples taken 6 wk later using a non-iodized dip are shown in Table 2. The difference, corrected to allow for cow and stall effects, was $25.12 \mu \mathrm{g} / \mathrm{kg}$ of milk at a standard error of $5.22 \mu \mathrm{g} / \mathrm{kg}$ of milk on both testing days. The iodine content of the samples with iodized dip was, therefore, significantly higher than that of the samples with non-iodized dip $(P=0.041)$. An influence of the milking stall could not be determined $(P=0.70)$.

In trial 3 , a mean dip success rate of $91.6 \pm 1.3 \%$ was obtained during the 4 milking sessions in the field test (Table 3). Based on the results of the single-sided $t$-test, the lower $95 \%$ confidence limit of mean dip success was $90 \%$ (i.e., the automated dipping system had an efficiency of at least 90\%).

The content of iodine considered normal in cow milk varies in the literature. Further studies showed mean iodine contents of 88 to $443 \mu \mathrm{g} / \mathrm{L}$ in milk (Bruhn et al., 1987; Preiß et al., 1997; Dahl et al., 2003; Travnicek et al., 2006; Paulíková et al., 2008). The iodine content of milk varies markedly by season: differences between the summer and winter season of 100 to $200 \mu \mathrm{g}$ iodine/ $\mathrm{kg}$ milk have been reported; in addition, the iodine fortification applied to the cow feed affects the iodine content of milk: a decrease of $1 \mathrm{mg}$ of iodine $/ \mathrm{kg}$ feed DM resulted in a decrease of 240 to $340 \mu \mathrm{g}$ of iodine $/ \mathrm{kg}$ of milk (Flachowsky et al., 2007).
The use of iodine-based teat dips has also shown to increase the iodine content in milk. This source of iodine can enter the milk in various ways, through skin absorption or as a residual remaining on the teats before the cluster is attached. Both the laboratory trial 1 and the field trial 2 showed an increase in iodine in the milk when the teats were exposed to iodine-based teat dip. Trial 1 showed an average $18.94 \mu \mathrm{g} / \mathrm{kg}$ increase and trial 2 showed an increase of $25.12 \mu \mathrm{g} / \mathrm{kg}$. This level is in line with previous studies, where teats were exposed to iodine teat dip through the accepted practice of hand dipping teats at the end of milking. Table 4 shows the results of various studies using dips of increasing strength. These results indicate the tendency of increasing iodine content in milk with increasing iodine level in dip. More results are needed to clarify whether automated dipping effects lower dip residues in milk than manually dipping.

In field trial 2 , the iodine content in the milk samples taken using an iodine teat dip was significantly higher $(25.12 \mu \mathrm{g} / \mathrm{kg} ; P=0.041)$ than that in the samples taken 6 wk later, after the automated dipping system had been changed to a non-iodine teat dip. This was not totally unexpected, as previous studies have shown that the act of manually dipping with an iodine solution will show an increase in iodine present in the milk (Conrad and Hemken, 1978; Galton, 2004). The increase of $25.12 \mu \mathrm{g} / \mathrm{kg}$, measured during the field testing of the automated dipping system, was consequently low compared with the values from those earlier studies. The 6 wk of time between sets of samples needs to be considered before drawing definitive conclusions based on the test results, as the iodine content could have been influenced by changes in feed or seasonal changes,

Table 3. Field-test dip success ${ }^{1}$

\begin{tabular}{lccccc}
\hline Item & Qmax (no.) & QDr (no.) & QwoDr (no.) & QwoD (no.) & DS (\%) \\
\hline Day & & & & \\
1 & 1,081 & 993 & 14 & 64 & 91.86 \\
2 & 1,145 & 1,065 & 11 & 78 & 93.01 \\
3 & 1,148 & 1,031 & 39 & 57 & 91.86 \\
4 & 1,167 & 1,072 & 102 & 278 & 91.63 \\
Total & 4,541 & 4,161 & &
\end{tabular}


Table 4. Additional iodine from postdipping, with results from the literature and our own tests

\begin{tabular}{llrll}
\hline $\begin{array}{l}\text { Dip iodine } \\
\text { level (\%) }\end{array}$ & $\begin{array}{c}\text { Milk iodine } \\
\text { increase }^{1}\end{array}$ & $\begin{array}{l}P \text {-value } \\
\text { method }\end{array}$ & $\begin{array}{l}\text { Dipping } \\
\text { Reference }\end{array}$ \\
\hline 0.1 & $35 \mu \mathrm{g} / \mathrm{L}$ & $<0.01$ & Manual & Galton et al. (1986) \\
0.5 & $29-32 \mu \mathrm{g} / \mathrm{L}$ & $<0.01$ & Manual & Galton (2004) \\
0.5 & $27-32 \mu \mathrm{g} / \mathrm{L}$ & $<0.01$ & Automatic & Galton (2004) \\
0.5 & $36 \mu \mathrm{g} / \mathrm{L}$ & $<0.01$ & Manual & Galton et al. (1984) \\
0.5 & $33-54 \mu \mathrm{g} / \mathrm{kg}$ & $<0.01$ & Manual & Aumont (1987) \\
0.5 & $19-25 \mu \mathrm{g} / \mathrm{kg}$ & $<0.05$ & Automatic & Own results (current study) \\
1.0 & $80-100 \mu \mathrm{g} / \mathrm{L}$ & $<0.01$ & Manual & Conrad and Hemken (1978) \\
1.0 & $90 \mu \mathrm{g} / \mathrm{L}$ & $<0.01$ & Manual & Galton et al. (1984) \\
1.0 & $76 \mu \mathrm{L} / \mathrm{L}$ & $<0.01$ & Manual & Galton et al. (1986) \\
\hline
\end{tabular}

${ }^{1}$ Milk density commonly ranges between 1.02 and $1.04 \mathrm{~kg} / \mathrm{L}$.

or both, outside the experiment's control (Flachowsky et al., 2007).

The results from trial 3 showed that the automated dipping system created a drop of dip at the end of the milk duct on $91.6 \pm 1.3 \%$ of the teats. Hogewerf et al. (2008) registered $87.8 \%$ of hand-dipped teats with a coverage of more than $60 \%$ of the teat skin (best score). When comparing these dip performances, the different evaluation criteria have to be considered as well as the principle of the investigated automated dipping system. With the investigated system, the dip is applied within a $360^{\circ}$ ring in the liner dome. As a consequence, a drop at the end of the milk duct is formed only when enough dip covers the teat skin. It might be possible that a more effective application of the disinfection and teat-conditioning agent could lead to better udder health with a fewer number of new IMI and possibly

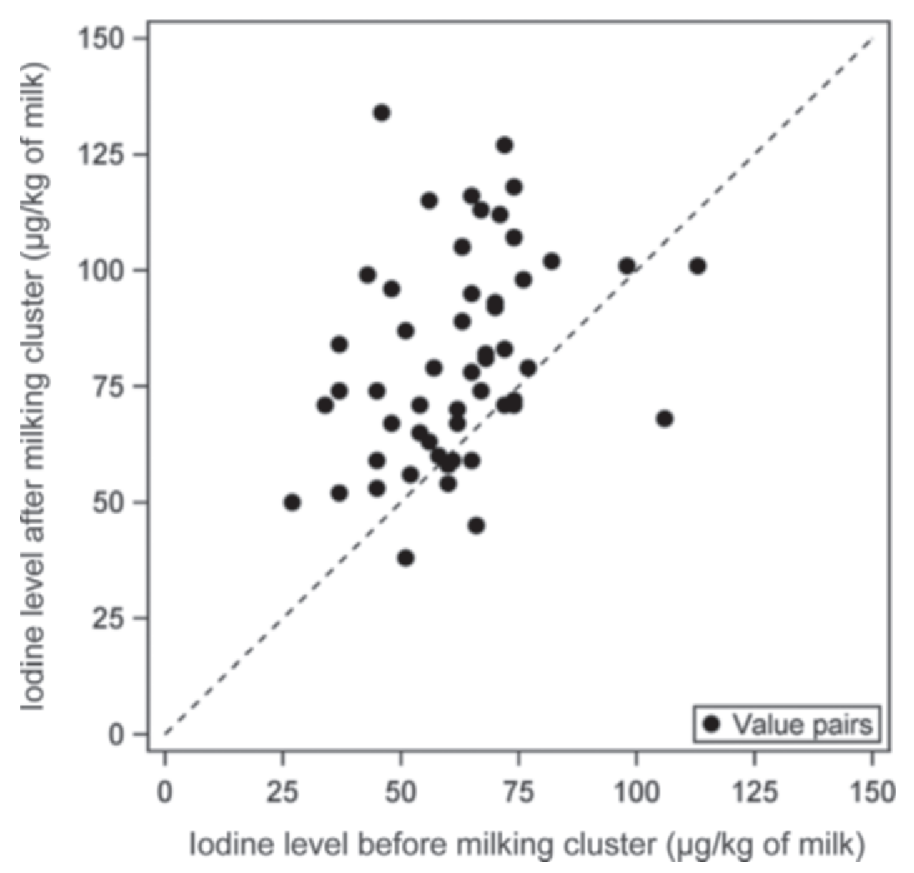

Figure 1. Scatter plot of the iodine content per process. a lower SCC. Removing the mundane task of dipping cows could also free up the operator to focus on more important tasks, such as udder preparation and proper attachment, leading to further improvements in udder health (Galton, 2004; Olde Riekerink et al., 2012).

As seen in the results of the laboratory and field tests, the iodine content of the tested milk was at a very low level for naturally occurring iodine levels in milk. The automated dipping system increased the iodine content of the milk by 18.9 and $25.1 \mu \mathrm{g} / \mathrm{kg}$ of milk under laboratory and under farm conditions, respectively. When compared with the large variations in iodine content that a result of the feed or the currently accepted practice of hand dipping, the iodine level increase measured from the Apollo cluster with the automated dipping function was very low and would not be considered a threat to food safety. Dip application was found to be consistent with the investigated automated system. The dipping success rate (percentage of teats with a drop of dip at the end of the milk duct) of the automated system was $91.6 \pm 1.3 \%$.

\section{ACKNOWLEDGMENTS}

The authors thank GEA Farm Technologies GmbH (Bönen, Germany) for financial support.

\section{REFERENCES}

Aumont, G. 1987. Milk iodine residues after a post-milking iodophor teat-dipping. Ann. Rech. Vet. 18:375-378.

Boddie, R. L., W. E. Owens, C. J. Foret, and P. Janowicz. 2004. Efficacy of a $0.1 \%$ iodine teat dip against Staphylococcus aureus and Streptococcus agalactiae during experimental challenge. J. Dairy Sci. 87:3089-3091.

Bruhn, J. C., A. A. Franke, and T. W. Smith. 1987. Iodine in California farm milk. J. Food Prot. 50:765-768.

Conrad, L. M., III, and R. W. Hemken. 1978. Milk iodine as influenced by an iodophor teat dip. J. Dairy Sci. 61:776-780.

Dahl, L., J. A. Opsahl, H. M. Meltzer, and K. Julshamn. 2003. Iodine concentration in Norwegian milk and dairy products. Br. J. Nutr. 90:679-685.

Flachowsky, G., F. Schöne, M. Leiterer, D. Bemmann, M. Spolders, and P. Lebzien. 2007. Influence of an iodine depletion period and 
teat dipping on the iodine concentration in serum and milk cows. J. Anim. Feed Sci. 16:18-25.

Galton, D. M. 2004. Effects of an automatic postmilking teat dipping system on new intramammary infections and iodine in milk. J. Dairy Sci. 87:225-231.

Galton, D. M., L. G. Petersson, and H. N. Erb. 1986. Milk iodine residues in herds practicing iodophor premilking teat disinfection. J. Dairy Sci. 69:267-271.

Galton, D. M., L. G. Petersson, W. G. Merrill, D. K. Bandler, and D. E. Shuster. 1984. Effects of premilking udder preparation on bacterial population, sediment and iodine residue in milk. J. Dairy Sci. $67: 2580-2589$.

Hogewerf, P. H., A. H. Ipema, C. J. A. M. de Koning, H. J. Schuiling, B. A. Slaghuis, V. Tancin, I. Ohnstad, and H. W. Barkema. 2008. Impact of automatic teat dipping and cluster flushing system on iodine residuals, milking characteristics and teat coverage. Pages
349-356 in Mastitis Control: From Science to Practice. T. J. G. M. Lam, ed. Wageningen Academic Publishers, Wageningen, the Netherlands.

ISO/DIN (International Organization for Standardization/Deutsches Institut für Normung e.V.). 2007. Milking machine installationsMechanical tests. ISO/DIN 6690. ISO, Geneva, Switzerland.

Olde Riekerink, R. G. M., I. Ohnstad, B. van Santen, and H. W. Barkema. 2012. Effect of an automated dipping and backflushing system on somatic cell counts. J. Dairy Sci. 95:4931-4938.

Paulíková, I., H. Seidel, O. Nagy, and G. Kováč. 2008. Milk iodine content in Slovakia. Acta Vet. (Brno) 77:533-538.

Preiß, U., C. Alfaro Santos, A. Spitzer, and P. R. Wallnöfer. 1997. Der Jodgehalt der bayerischen Konsummilch (Iodine content of Bavarian consumer milk). Z. Ernährungswiss. 36:220-224.

Travnicek, J., I. Herzig, J. Kursa, V. Kroupova, and M. Navratilova. 2006. Iodine content in raw milk. Vet. Med. (Praha) 51:448-453. 